\title{
The Day the Milk Went Sour: Bridging Epistemology and Ontology in Latour's Empirical Philosophy
}

Citation for published version (APA):

Penders, B., \& Russo, F. (2018). The Day the Milk Went Sour: Bridging Epistemology and Ontology in Latour's Empirical Philosophy: Bruno Latour, by Gerard de Vries. Science as Culture, 27(3), 398-402. https://doi.org/10.1080/09505431.2018.1476480

Document status and date:

Published: 01/01/2018

DOI:

10.1080/09505431.2018.1476480

Document Version:

Publisher's PDF, also known as Version of record

Document license:

Taverne

Please check the document version of this publication:

- A submitted manuscript is the version of the article upon submission and before peer-review. There can be important differences between the submitted version and the official published version of record.

People interested in the research are advised to contact the author for the final version of the publication, or visit the DOI to the publisher's website.

- The final author version and the galley proof are versions of the publication after peer review.

- The final published version features the final layout of the paper including the volume, issue and page numbers.

Link to publication

\footnotetext{
General rights rights.

- You may freely distribute the URL identifying the publication in the public portal. please follow below link for the End User Agreement:

www.umlib.nl/taverne-license

Take down policy

If you believe that this document breaches copyright please contact us at:

repository@maastrichtuniversity.nl

providing details and we will investigate your claim.
}

Copyright and moral rights for the publications made accessible in the public portal are retained by the authors and/or other copyright owners and it is a condition of accessing publications that users recognise and abide by the legal requirements associated with these

- Users may download and print one copy of any publication from the public portal for the purpose of private study or research.

- You may not further distribute the material or use it for any profit-making activity or commercial gain

If the publication is distributed under the terms of Article $25 \mathrm{fa}$ of the Dutch Copyright Act, indicated by the "Taverne" license above, 


\title{
The Day the Milk Went Sour: Bridging Epistemology and Ontology in Latour's Empirical Philosophy
}

\author{
Bruno Latour, by Gerard de Vries, Polity, Cambridge, UK, 2016.
}

Students or scholars pursuing the philosophy of science, as a field of inquiry, once had a life-time of reading and writing ahead of them. Science as a practice, as a cultural activity, as employment, or as a political struggle were but deviations of the study of science as a process, method, or vocation. The latter required little direct interaction with scientists, and while it was, of course, never a bad idea, collecting empirical material - or data - was not a requirement to do good philosophy. The era of armchair philosophy is coming or, according to others, has already come - to an end. The philosophy of science has joined the history, sociology, and anthropology of science in employing empirical modes of inquiry. This change was neither fast nor easy, and no single philosopher can be credited for it. However, there is one whose name is inevitably mentioned in this context, and that is Bruno Latour.

He is unquestionably a thinker deserving a space in Polity's Key Thinkers series. His work has been influential to several fields, from sociology to philosophy, from religious studies to law. Gerard de Vries, in his book Latour, takes up what we consider to be a very difficult challenge: reconstructing the development of Latour's thinking by showing a red line that, through contributions across nearly four decades, confers coherence to his work: telling the tale of how Latour grew to be a philosopher and how philosophy grew more empirical. The book is organised into six chapters, each focussing on a specific period (and published work) of Latour's career. The exposition is largely chronological although some themes, as De Vries takes pains to show, consistently recur in Latour's production.

Here we introduce three discussion points, both as an evaluation of De Vries' work and as a reading aid for those attempting to digest De Vries' reconstruction of Latour: the context in which thinkers work, the disciplinary positioning of Latour including consequences of this positioning, and De Vries' display of Latour's treatment of the relationship between ontology and epistemology.

\section{Thinkers in context}

Key contemporary thinkers are not lonely geniuses. This is the impression we get from De Vries once we start reading Latour. De Vries chronicles Latour's path like Latour himself chronicled that of Pasteur and Pasteur chronicled that of the microbes. Both Latour and Pasteur are very capable at what they do - of course - but only capable because they are not doing it all by themselves. De Vries quotes Latour: 'I must go looking for friends and allies, interest them, draw their attention' (p. 63). De Vries is unquestionably one of those friends and allies, yet the label 'key contemporary thinkers' means that this group is significantly larger. Some of its members feature in De Vries' book by name or description, but most will diligently take up their role as readers of the book - similar to the way they read some, or most, of Latour's work itself. 
In the opening chapter, De Vries takes pain to explain the intellectual struggle Latour went through to position himself with respect to scholarly communities such as sociologists and anthropologists of science and philosophers of science. However, after the first chapter, the surroundings of Latour fade into the background, and its philosophical novelty is foregrounded, obscuring the context of its origin. This creates a tension in the book: on the one hand the early work of Latour is contextualised with respect to neighbouring communities, on the other hand, subsequent work of Latour is presented more in isolation, as if he were this lonely genius.

As it unfolds through the pages, De Vries subjects Latour's philosophy to trials. Again, at least initially. Does it hold up? Does it compare favourably to competing epistemologies and ontologies? Not all trials are, at first at least, mastered successfully, as displayed by a page-long collection of critiques and dismissals of Irreductions. De Vries argues why these critiques, to him and Latour, do not hold, but also admits that the presentation of the arguments was, at that time, far from ideal. Latour's alliance with the sociology of science and knowledge was, in the beginning, helpful. It helped his ideas spread, and his prestige and reputation grow. In De Vries' reconstruction, however, Latour aligned himself with an intellectual programme he was, in fact, leaving behind - a claim that only makes sense with the benefit of hindsight. At the time, neither Latour nor his critics could know this, although the discomfort flowing from the mismatch may have been painfully obvious. Alas, we were not there.

\section{Intersecting disciplines and approaches}

The question of how to locate Latour in the constellation of disciplines interested in the sciences is not independent of the question of how disciplines and approaches intersect. It takes nearly half of the book to get to Actor-Network Theory (ANT). We have, by that time, already gone through close to two decades of Latour's thinking as reconstructed by De Vries. Actants, intermediaries, mediators, and translations are introduced, allowing the reader to see how exactly ANT differs from other competing approaches to understanding collectives, organisations, movements, or the social at large, as living networks of moving relationships held together by an immense amount of work. The actions out of which this work is built are, however, unknowns, part of what has to be explained and understood alongside the connections that form the network that hosts the actions. Through ANT, Latour reimagines sociology - if we can still use the word - as a process of analysing group formation and action as they help build structures, consisting of stabilised translations and their add-ons.

Though this revised and improved approach - developed by studying the sciences, leading to new ways of understanding the fabric of the social - other practices can be targeted too. Thus, Latour moves into the study of Law. Legal reasoning is an act of work too, in which actions - speech actions, to be more precise - take place. There he finds value-objects and conditions for their travel. The legal actor-network is different from the scientific actor-network because of what circulates and what it produces the latter being either scientific facts or legal ties, the former being long lists of different actors, materials, claims, utterances, and value-objects. What they both do is travel well beyond the lab or courtroom, with science making everything scientific (or the lab expanding into every crack of society), and the law making everything legal (or the courtroom expanding into every crack of society).

Yet, for Latour, science and law are but shadows of the true adversary defying explanation, or better perhaps, description is modernity itself. De Vries shows how Latour 
rewrites one of the seminal texts in the sociology of scientific knowledge to fit his philosophy, where not eminent men but a small pump containing an even smaller feather at the centre of a very large network of many other human and inhuman entities gave rise to the modern constitution, separating nature from society. But it turns out we are terrible at performing this separation, and continue to produce and rely on hybrids of both all the time. By assigning those hybrids to either culture or nature, we purify their history. Those hybrids and the ways in which they emerge, the roles they play in our lives and in our societies, the collectives and networks they embody are assigned the 'nature' label. But what is worth focusing on in our complex world, De Vries writes, are 'hybrid thoughts in a hybrid world,' precisely what, to borrow Latour's famous words, never allowed us to properly became modern. In this missed achieved of modernity lies Latour's complex intertwining of ontology and epistemology, as we explain next.

\section{The relation between ontology and epistemology}

Latour's hybrids are histories of humans and non-humans, describing their existence through time while it changes. They have a variable ontology. This allows Latour to argue that it was only after Pasteur, and not before him, that lactic yeast that made milk go sour. This relational ontology is a lot better than relativism - 'poor man's philosophies' (p. 135) - De Vries agrees. For Latour, the world is about relationships, not about what relates to what. Why should we care? De Vries argues that those relationships are causing upheaval and crisis in our world and we need tools to understand them, rather than try and sweep them under the carpet. The issue is delicate, and ultimately concerns the complex relation between ontology and epistemology - a tension that is not just present in Latour's work, but that has been at the centre of longstanding philosophical debates.

De Vries seems to agree with Latour that we can easily dispose of epistemology and move straightforwardly to ontology. Easier said than done, however, and perhaps puzzling that the issue is not problematised in De Vries' reconstruction of Latour. One could, in fact, wonder how an 'empirical philosopher' can make such a long jump from epistemology to ontology, and whether in this jump something got lost, notably the role of epistemic agents that interact with reality. What is at stake for empirical philosophy in general, and for Latour in particular, is not so much the pluralist ontology, but whether one can build an ontology in the abstraction of epistemology.

In the final and longest chapter, De Vries chronicles Latour's gaze widening to practices far beyond science and the law. Almost reluctantly, De Vries introduces 'beings-asbeings' and 'beings-as-other,' the latter being more interesting, surviving only when their chain of translations is unbroken, when their relationship with others are fruitful and their ability to face trials is unwavering. However, one might say, trials require judges. Ontology requires epistemology and epistemic agents. Using 'beings-as-other,' for lack of a better word, allows tracing different coexisting modes of existence for those beings, making them ontologically plural. In the example, De Vries examines, a drug can have a legal and a scientific mode of existence. Similarly, this plural ontology can apply to everything, well beyond science.

Experience, De Vries argues, is to be at the heart of Latour's approach to empirical philosophy: 'Empirical philosophy begins and ends with experience; but it acknowledges that that in between a lot of thinking, sorting and work may have to be done' (p. 169). In this philosophy, the concept of construction no longer suffices. Latour replaces it with 'instauration', allowing him to include what yet has to happen into the chain of relations 
- the future, a promise that has to be looked after, cared for. The fact a scientist endeavours to build, the novel an author promised to write, they cause them to worry, blending the normative with the tangible and subjecting both to the empirical approach to philosophy.

In the long list of modes of existence, different values travel through chains of translations, while in the process, all beings speak back, requiring us to care for, be responsible for the chain of translations, whatever that chain transports, be it legal grounding, reference, love, or many others. De Vries reproduces Latour's pivot table of modes of existence in full, concluding that after Latour abolished nature in his early work, and society in his Reassembling the Social, he is repeating this with economy in An Inquiry into Modes of Existence. Here too, contextualising Latour would have helped. There is only a quick mention of Simondon in the text and Souriau is ignored completely. These are the philosophers who started inquiring into modes of existence and that, arguably belong to the school of thought Latour stems from. In fact, there is a broader story to be told, about whether - or how - Latour's complex thinking is embedded or originated in the tradition of French epistemology, starting from Canguilhem and Bachelard.

Only towards the end does De Vries explicitly venture into asking what Latour's work provides us with, rather than describing or summarising it. The key elements, he argues, are Latour's ability to redescribe who we are without leaving something behind (or out), including science, nature, power, lust, and others, that competing philosophies throughout history have failed to capture. Latour is able to position the earth as a collective that is ontologically plural - Gaia. The earth-as-a-plural collective consists of relationships, associations, connections, and translations. It is a being-as-other that causes us to worry, that requires our care and our responsibility. To De Vries, our old ideas of modernity, according to which nature and culture are clearly separable, cannot deliver those. Latour's empirical take on philosophy - one that does not include modernity - can.

\section{Epistemological-ontological levels}

What we seek from introductions into key contemporary thinkers is not why they are right. Neither do we want to be baffled by their genius. Rather, we want to find out how their thinking was received, both positively and negatively, and especially how it changed the thinking of others. We would have hoped to encounter arguments that demonstrate why Latour's work is so innovative, so different - rather than mere claims about it - preferably though discussions of debates surrounding Latour and the reception of his work. Ultimately, we seek to learn from the receptions and critique of Latour's work as much as from its content.

Bruno Latour by Gerard de Vries is, as he writes in the preface, an introduction to Latour's work. Yet, De Vries argues that Latour expects the readers of An Inquiry into Modes of Existence to know his work. Similarly, De Vries relies on previous knowledge from his readers. It is difficult to imagine a reader totally unfamiliar with Latour, possibly because of the multiple audiences having an interest in Latour. As a consequence, De Vries's Latour is not an immediate, nor an obvious, teaching resource. Rather, we would suggest this is a companion reader to Latour - whose notable inaccessibility is displayed with humour by Twitter’s Bruno @LatourBot, tweeting translated sentences from Latour's work which (in isolation) make no sense whatsoever.

Despite this, the book offers numerous interesting leads for philosophers of science or those engaged in science studies. First, the intellectual biography of Latour shows us that disciplinary boundaries neither are, nor should be, impenetrable. Of course, they are not 
absent, for they imply different epistemic agents, conceptual tools, core concepts and, to a lesser degree, institutionalisations. However, historians, sociologists, anthropologists, philosophers can strengthen their dialogues across these semi-permeable boundaries.

The primary intellectual disputes currently limiting such exchange are the unclear translations between epistemological and ontological levels. Latour's attempt to build a trading zone between them, centring on modes of inquiry, is but the very first step. Second, we need to ask ourselves what the added value of the label 'empirical philosophy' is. Does the prefix influence the chances of constructive and favourable interactions across disciplinary boundaries? We would argue so. The label 'empirical,', however, has to be contextualised in developments in our respective fields. It is an adjective that is assumed and rarely qualified in STS, indicating its commonality, whereas it invites mainly questions in the philosophy of science. What this reconstruction of Latour's work brings us, therefore, is a rationale for an empirical approach; such approach may be perceived as uncomfortable - and yet necessary - by those sitting in either camp: ethnography or philosophy, epistemology, or ontology.

Bart Penders

Department of Health, Ethics \& Society, Care and Public Health Research Institute (Caphri), Maastricht University, Maastricht, Netherlands b.penders@maastrichtuniversity.nl (i) http://orcid.org/0000-0002-2661-9181

Federica Russo Department of Philosophy, Faculty of Humanities, University of Amsterdam, Amsterdam, Netherlands 